International Journal of Social Science and Economic Research

ISSN: 2455-8834

Volume:06, Issue:06 "June 2021"

\title{
ROLE OF WOMEN IN THE GREEN GROWTH PROCESS
}

\author{
Trishamani Deka \\ Research Scholar, Gauhati University \\ DOI: 10.46609/IJSSER.2021.v06i06.006 URL: https://doi.org/10.46609/IJSSER.2021.v06i06.006
}

\begin{abstract}
With growing concern for environment World is promoting Green Economy to ensure sustainable development which can perceive growth along with protecting our mother nature. Moreover, growth inclusive of women players is also getting importance as a strategy for development in recent years. Women are engaged in various activities from working to fulfill basic necessities to leading social developments since decades. Green economy provides opportunities for women to engage in better job and attain higher social standards. But, it also possesses a threat of losing potential benefits and raising gender inequality at the early stage of growth which can be seen particularly in developing countries. However, women can play a vital role in achieving the targets of green economy.
\end{abstract}

Key word: sustainable development, green growth, participation and benefit of woman.

\section{Introduction}

Traditional economic practices advocate use of scarce resources to productive uses in the most efficient manner. Nature, which is the reservoir of resources, provides raw materials in the production process and also acts as a sink to the waste generated in the production and consumption process. The traditional economic model though uses natural resources but fails in valuing these resources. As a result, the pressure on environment increases and it creates serious environmental damage which in turn creates a negative impact upon the economy as well as society. The changing climate and environmental degradation pose a threat to the living of mankind as well as all other living creatures and also disrupts economic and social activities. This induced the need for development that is sustainable and long lasting which provides growth of the economy and society along with protecting the environment. The idea of inclusive green economy is emerging in the World scenario which focused growth that is equitable, sustainable and interdependent.

Women play a vital role in the process of growth. Economic development emphasizes the need for women empowerment in terms of asset holding and social standards in order to fulfill the 


\section{International Journal of Social Science and Economic Research}

millennium development goals. In the growth process though women play an active part, the work or the effort provided by women are often unrecognized or undervalued. The gender gap is widening with the development run. It is observed that the social standard of women around the World is improving but inequality has also risen over the years. The transition to green economy requires a fundamental shift in the production, consumption and asset holding pattern of the society which can influence the ongoing aspects of women empowerment.

\section{Objectives}

The paper tries to fulfill following objectives:-

1. The paper tries to summarize the basic idea of green economy, and,

2. The impact of transition to green economy on women.

\section{Methodology}

This study is descriptive in nature and the data used for analysis are derived from secondary sources. The main sources of secondary data are the earlier discussion by other authors, journals, ILO and UNEP reports and various statistics provided by the websites.

\section{Green Economy}

Green economy is defined as the one that improves human well-being and social equity while at the same time reduces the environmental risk and ecological scarcities. [UNEP 2011]. The UNEP report pointed that if unchecked the effect of climatic changes would cause around 250,000 deaths per year between 2030 and 2050. Moreover the rapid increase in pollution and land degradation would cause a loss of around 2 million hectares of agricultural land and around $84 \%$ population of the World would be exposed to poor air quality. This environmental degradation not only harms the health of the people but also perpetuates poverty and hunger as poorer health would reduce ability to work and as a result economic productivity would decline. It also has an impact upon rising inequality. As the bottom part of population largely depends on environment for their livelihood, degradation of natural resources would increase their struggle for living and inequality would be widened. As for global wealth concentration, the richest $1 \%$ people of the World have control around half of the global assets while the half of World's population owns only $1 \%$ of total assets. [UNEP 2015].

In 2008, UNEP proposed and anchored 'Green Economy Initiative (GEI) to achieve the goal of sustainable development. In 2012, the Rio +20 Summit Report "The Future We Want" emphasized the importance of green economy in poverty alleviation and sustainable development goals.[UNEP 2015]. The green economy is based on three bottom lines: economic 


\section{International Journal of Social Science and Economic Research}

ISSN: $2455-8834$

Volume:06, Issue:06 "June 2021"

growth, sustainability and social equity. Thus, the idea of green economy emphasized the creation of green jobs ${ }^{1}$ with sustainable resource allocation which can reduce social inequality and augment productive ability of the economy.

\section{Green growth}

Green growth provides an ecological dimension to the growth process. The OECD defines green growth as 'fostering economic growth and development, while ensuring that natural assets continue to provide the resources and environmental services on which our well-being relies'. Green growth can be achieved with the creation of green jobs. Creating green jobs would induce people's perception towards conserving the ecological resources along with the reduction of social inequality. For example, creating jobs in the renewable energy sector would increase energy supply in unserved areas while at the same time increases social development. In Brazil, China and the United States, the waste sector employs 12 million people out of which majority are poor.[UNEP 2015]. However, it is feared that green growth can result in loss of jobs at the early stage of transition process. This is because green growth requires low carbon life style which wipes out many industries initially and this would cause a rise in the existing unemployment rate. This problem can be tackled by proper macroeconomic policies so that more and more green jobs can be created and the social stability is maintained.

\section{Women in the green growth}

All over the world, women bear most of the responsibility of household and children which inclines them to keep out of the workforce. Most of the work done by women is unrecognized or undervalued and there exists wage discrimination for women in the workplace. Although presence of women in the workforce is growing, gender equality is far to reach. Gender inequality is fueling the inequality gap within and across the nations. The 2008 Sustainable Society Index puts UK and US in $50^{\text {th }}$ and $66^{\text {th }}$ position respectively. It has been observed that single mothers are the poorest in these rich societies. The Gender Gap Index of World Economic Forum shows a positive correlation between gender equality and wealth per capita. Greater gender equality shows better economic development, whereas the economy cannot prosper when the women are left behind.[ Stevens 2010]. Due to patriarchal attitudes and social conditioning, current employment pattern is discriminating for women and if the situation persists the fundamental shift to sustainable growth will deteriorate the social standard of women more. Green growth will put higher restriction upon natural resource utilization and it will have a regressive impact on poorer households. Low carbon emission will be achieved only when the bottom part of population can have access to cleaner energy sources.

1 Green jobs refer to the transformation of economies, enterprises, workplaces and labour markets into a sustainable, low-carbon economy providing decent work. (ILO 2012) 


\section{International Journal of Social Science and Economic Research}

ISSN: $2455-8834$

Volume:06, Issue:06 "June 2021"

Governments of various countries adopted green economy strategies and it is expected that 50 million green jobs will be created in the coming years, of which about $75 \%$ jobs will be related to renewable energy and green building. The share of women in the workforce engaging in energy, technical or construction sector is extremely low. To increase participation of women in the green growth, the 1992 Women in Apprenticeship and Nontraditional Occupations (WANTO) Act qualifies women for green training so that more and more green jobs can be accessed by the women.[ Stevens 2009]. To achieve the goal of social equity in the green economy, reducing gender gap by giving better opportunities to women is of utmost importance. In developed nations green jobs are usually created in energy, engineering and construction sector where women participation is low. Therefore it is necessary to provide proper training and opportunities to women so that female labor force participation in these sectors increases and as a result equitable growth is achieved. However, in case of developing nations where overall level of female workforce participation is low and women are basically marginalized workers, achieving sustainability and equity simultaneously is a difficult task. In developing countries green jobs can be created in agricultural, forestry, eco tourism etc. where opportunities and possibilities for women are very high. But due to lack of skill and proper training to achieve sustainability in these traditional practices, women workforce is undervalued. There is a strong need to implement suitable cooperative policies so that the objectives of green growth are materialized. If gender perspective in the green growth is ignored, it will hinder the success of green economy as the social inequality will increase.

\section{Examples of women participation in the green growth}

In West Africa, women are contributing to the green economy by engaging themselves in the production of organic cotton. While conventionally grown cotton are criticized for using heavy amount of pesticides and causing environmental damage, organic cotton creates main entry to women as a producer of cash crop in Africa.[DCED 2012]

Women in the coastal Kenyan town of Gazi have established a community-based tourism venture that profits from the value of the mangrove's scenic beauty and biodiversity. Similarly, eco tourism business is becoming popular among the women of Brazil, Costa Rica and Thailand.[ UNWTO 2009].

The Grameen Sakti microloan initiative in Bangladesh boosted women participation in the energy sector. This initiative helped to install more than 1 lakh solar home system in rural communities and has trained more than 5000 women as PV technician and maintenance worker. The loan provided to women enables them to set up their own renewable energy businesses which in turn induce better access to cleaner energy and improved health benefits.[ ILO 2015] 


\section{International Journal of Social Science and Economic Research}

ISSN: $2455-8834$

Volume:06, Issue:06 "June 2021"

In the Pune city of India, a union is promoting socially and ecologically innovative model of waste recovery. This initiative secured employment for about 9500 waste collectors of whom $90 \%$ are women. The union is promoting the separation of waste at the household level whereby 'families divide their waste into biodegradable and non-biodegradable. The waste collectors go from house to house to collect it and then sell what can be sold. What cannot be reused is sent to the dump, and the biodegradable waste is composted at the source. Through such initiatives, empowered unions can generate economic savings and environmental benefits as well as social gains for women workers'.[ ILO 2015].

The Barefoot solar programme has been pioneering solar electrification of rural, remote, nonelectrified villages since 2005. This initiative targets sustainable electrification through women's empowerment approach through capacity building. Poor women who are semi literate are trained as solar engineers and they build solar kit for their community in a joint effort.[ DCED 2012].

These examples though explain a small change but carry a powerful message towards the transition to green economy. The opportunities and possibilities for women in green growth are higher. But, it can be materialized only when effective macroeconomic policies are adopted. Without proper policy making, su stainable growth can widen the persistent gender gap.

\section{Conclusion}

Thus, it is evident that women play an important role in achieving the objectives of sustainable development. Gender inequality makes green economy inconsistent. The macroeconomic policies and interdependent strategies among the nations must be taken carefully so that the currently prevailing gender inequalities are not transferred to emerging green economy. The lack of progress on gender equality hinders sustainable development. Sustainability in the economy, society and environment will rapidly increase if women are engaged in more productive and decision making activities. Investment in renewable energy sector will contributes to environmental and social goals and engagement of women in these sectors will enhance efficiency of the adopted strategies. Moreover, incorporating sustainability in traditional agricultural practices will lead to conservation of ecological resources as well as provision of better opportunities for women.

\section{References}

1) 'A Gender Perspective on the 'Green Economy', Women's Major Group position paper in preparation for the United Nations Conference on Sustainable Development 2012, Women Rio+20 Steering Committee, March 2011. 
International Journal of Social Science and Economic Research

ISSN: 2455-8834

Volume:06, Issue:06 "June 2021"

2) Bapna M. \& Talberth J. (2011), Q\&A: What is a "Green Economy?", Retrieved from https://www.wri.org/blog/2011/04/qa-what-green-economy-0 on 26/03/2019.

3) “GENDER EQUALITY AND GREEN JOBS”, Green Jobs Programme, International Labour Organization, 2015.

4) Nevena P. (2016) "Women in the Green Economy", Journal of Women's Entrepreneurship and Education, pp: 97-110.

5) Stevens C. (2009) Green Jobs and Women Workers: Employment, Equity, Equality,, Draft report for SustainLabour.

6) Stevens C. (2010), “Are Women the Key to Sustainable Development?” Sustainable Development Insights, April 2010.

7) "UNCOVERING PATHWAYS TOWARDS AN INCLUSIVE GREEN ECONOMY: A SUMMARY FOR LEADERS”, United Nations Environment Programme, 2015.

8) United Nations Environment Programme (2011). Towards a Green Economy: Pathways to Sustainable Development and Poverty Eradication-A Synthesis for Policy Makers. Nairobi.

9) United Nations World Tourism Organization (UNWTO), 2009, Greening the Global Economy through Sustainable Tourism.

10) "Women's participation in green growth - a potential fully realised?" A scoping study for the Green Growth Working Group (GGWG), Donor Committee for Enterprise Development (DCED) 2012. 